Synt hesi s and El ect rochemical Properties of $\mathrm{C} / \mathrm{Li} \mathrm{MPO} 4$ CathodeNateri al s by Compl ex Pol ymer i zed Net hod

\begin{tabular}{|l|l|}
\hline 著者 & $\begin{array}{l}\text { FUJI TA At sushi, I SOBE Fum nar i, KODERA } \\
\text { Takayuki, OG HARA Takashi }\end{array}$ \\
\hline $\begin{array}{l}\text { j our nal or } \\
\text { publ i cat i on t i t l e }\end{array}$ & Key Engi neer i ng Nat er i al s \\
\hline vol une & 485 \\
\hline page $r$ ange & $115-118$ \\
\hline year & $2011-07$ \\
\hline URL & ht t p: //hdl . handl e. net /10098/6824 \\
\hline
\end{tabular}




\title{
Synthesis and Electrochemical Properties of $\mathrm{C} / \mathrm{LiMnPO}{ }_{4}$ Cathode Materials by Complex Polymerized Method
}

\author{
Atsushi Fujita, Fuminari Isobe, Takayuki Kodera, and Takashi Ogihara \\ Graduate School of Engineering, Materials Science and Engineering, University of Fukui, 3-9-1 \\ Bunkyo, Fukui-shi, Fukui, Japan \\ ogihara@matse.u-fukui.ac.jp
}

Keywords: $\mathrm{LiMnPO}_{4}$, Olivine, Lithium ion battery, Complex polymerized method

\begin{abstract}
C} / \mathrm{LiMnPO}_{4}$ materials were synthesized by the complex polymerized method. An orthorhombic olivine type structure was obtained by calcination at temperatures over $973 \mathrm{~K}$ under an argon/hydrogen (5\%) atmosphere. Differential thermogravimetric analysis showed that the carbon content of $\mathrm{C} / \mathrm{LiMnPO}_{4}$ was about $65 \mathrm{wt} \%$. The initial discharge capacity of $\mathrm{C} / \mathrm{LiMnPO}_{4}$ calcined at $973 \mathrm{~K}$ was $135 \mathrm{mAh} / \mathrm{g}$ at $0.1 \mathrm{C}$ and $60 \mathrm{mAh} / \mathrm{g}$ at $1 \mathrm{C}$.
\end{abstract}

\section{Introduction}

Lithium ion batteries are expected to be used in electric vehicles and hybrid electric vehicles. $\mathrm{LiCoO}_{2}$ and $\mathrm{LiMn}_{2} \mathrm{O}_{4}$ have been studied for their use as cathode materials in lithium ion batteries. $\mathrm{LiCoO}_{2}$ has high capacity, but it is very expensive and unstable under high temperatures. $\mathrm{LiMn}_{2} \mathrm{O}_{4}$ is cheap and has a high operating voltage. But it has an unstable cycle performance under high temperatures. On the other hand, $\mathrm{LiMnPO}_{4}$ is cheap and has a relatively high theoretical capacity of $170 \mathrm{mAh} / \mathrm{g}$ and stable cycle performance at high temperatures. Batteries made from $\mathrm{LiMnPO}_{4}$ cathode are rechargeable approximately $4 \mathrm{~V}$. However, it has very poor electrical conductivity and lower capacity at higher charging/discharging rate [1-3].

Therefore, composites of $\mathrm{LiMnPO}_{4}$ with conducting materials such as carbon have been prepared [4-6]. It is expected that the complex polymerized method can be used to prepare cathode powders with carbon sources at lower temperature, similar to the conventional sol-gel method. Powder preparation using the complex polymerized method involves the formation of polybasic acid chelates through a reaction between a carboxylic acid and an organic compound with a hydroxyl group. When these chelates are heated in polyhydroxyl alcohol, esterification occurs, leading to the formation of a polymeric species with a uniform distribution of cations. The polymeric species retains homogeneity on the molecular scale and calcines at low temperatures to yield an oxide with a precisely controlled chemical composition [7-8]. The carboxylic acid and the organic compound utilized in the esterification are also used as carbon sources. In this paper, the synthesis and electrochemical properties of $\mathrm{C} / \mathrm{LiMnPO}_{4}$ cathode materials by the complex polymerized method are described.

\section{Experimental procedure}

$\mathrm{LiNO}_{3}, \mathrm{Mn}\left(\mathrm{NO}_{3}\right)_{2} \cdot 6 \mathrm{H}_{2} \mathrm{O}$, and $\mathrm{NH}_{4} \mathrm{H}_{2} \mathrm{PO}_{4}$ were used as the starting materials. They were weighed in molar ratio of $\mathrm{Li}: \mathrm{Mn}: \mathrm{P}=1: 1: 1$ and dissolved in a citric acid (anhydrous, $\mathrm{C}_{6} \mathrm{H}_{8} \mathrm{O}_{7}$ ) solution. Furthermore, ethylene glycol $\left(\mathrm{C}_{2} \mathrm{H}_{6} \mathrm{O}_{2}\right)$ was added to the starting solution. The concentrations of starting materials were $0.1 \mathrm{~mol} / \mathrm{dm}^{3}$ each. The concentrations of citric acid and ethylene glycol were $1.5 \mathrm{~mol} / \mathrm{dm}^{3}$ each. After mixing with a magnetic stirrer, the solution was heated at $413 \mathrm{~K}$ for $24 \mathrm{~h}$ to remove water and to accelerate the esterification between citric acid and ethylene glycol. The solution was condensed by heating at $573 \mathrm{~K}$, yielding tar-like precursors. The precursors were milled for $12 \mathrm{~h}$ by ball mill with zirconia balls. The precursor powders were calcined at $973 \mathrm{~K}$ or $1073 \mathrm{~K}$ for $3 \mathrm{~h}$ in an electric furnace under an argon/hydrogen (5\%) atmosphere. The heating and cooling rates were 5 $\mathrm{K} / \mathrm{min}$. 
The carbon content was measured by differential thermal analysis/thermal gravimetry (DTA-TG, Shimadzu Corporation DTG-60). The crystal phases of the precursor powders and the obtained powders were observed by powder X-ray diffraction (XRD) using $\mathrm{CuK} \alpha$ radiation (XRD-6100, Shimadzu). The chemical compositions of the obtained powders were determined by inductively coupled plasma atomic emission spectroscopy (SII, SPS-7800). The morphologies of obtained powders were observed with a scanning electron microscope (SEM, JSM-6390, JEOL). The specific surface areas (SSA) of the obtained powders were measured by the BET method using nitrogen gas adsorption (BELSORP-mini, Bel Japan). The organic species in the obtained powders were observed by Fourier transform infrared spectroscopy (FT-IR, NICOLETiSO10, Thermo Fisher Scientific).

A C/LiMnPO 4 cathode was prepared using $80 \mathrm{wt} \%$ calcined powders, $10 \mathrm{wt} \%$ polyvinylidene fluoride as a binder, and $10 \mathrm{wt} \%$ acetylene black as an electric conducting agent in $\mathrm{N}$-methyl-2-pyrrolidione. These materials were mixed using an agate mortar, creating a slurry of $\mathrm{C} / \mathrm{LiMnPO}_{4}$ cathode material. The slurry was coated on aluminum foil and then dried at $373 \mathrm{~K}$ for 24 h. A polypropylene sheet was used as a separator. A solution of $1 \mathrm{~mol} / \mathrm{dm}^{3} \mathrm{LiPF}_{6}$ in ethylene carbonate/diethyl carbonate (1:1) was used as the electrolyte. A lithium sheet was used as an anode. The electrochemical properties of $\mathrm{C} / \mathrm{LiMnPO}_{4}$ cathodes were examined using CR2032-type coin cells. These coin cells were set up in a glove box under an argon atmosphere. The rechargeable capacity and cycle performance of the $\mathrm{C} / \mathrm{LiMnPO}_{4}$ cathodes were measured with a battery tester (Hosen, BTS2004) between 2.0 and $4.6 \mathrm{~V}$ at $0.1 \mathrm{C}$ and $1 \mathrm{C}$.

\section{Results and discussion}

To estimate the carbon content in the obtained powders by the complex polymerized method, DTA-TG analysis was carried out. The exothermic peak with a weight loss of $65 \mathrm{wt} \%$ was observed in the DTA-TG curve. It was found there was a large amount of carbon in the obtained powders. The crystal phase and crystallinity of the precursor and calcined powders were identified by XRD. Figure 1 shows XRD patterns of the precursor and calcined powders obtained at the temperatures indicated. The precursor powders were not crystallized, while the calcined $\mathrm{LiMnPO}_{4}$ powders had high crystallinity. The diffraction patterns were in agreement with an orthorhombic olivine structure. The impurity phase peak was not observed. No evidence for diffraction peaks of crystalline carbon appeared in the diffraction patterns; this indicates that the carbon generated from ethylene glycol and citric acid was amorphous and that the presence of carbon did not influence the crystal structure of $\mathrm{LiMnPO}_{4}$. Molar ratios of the powders calcined at $973 \mathrm{~K}$ and $1073 \mathrm{~K}$ were determined by ICP to be

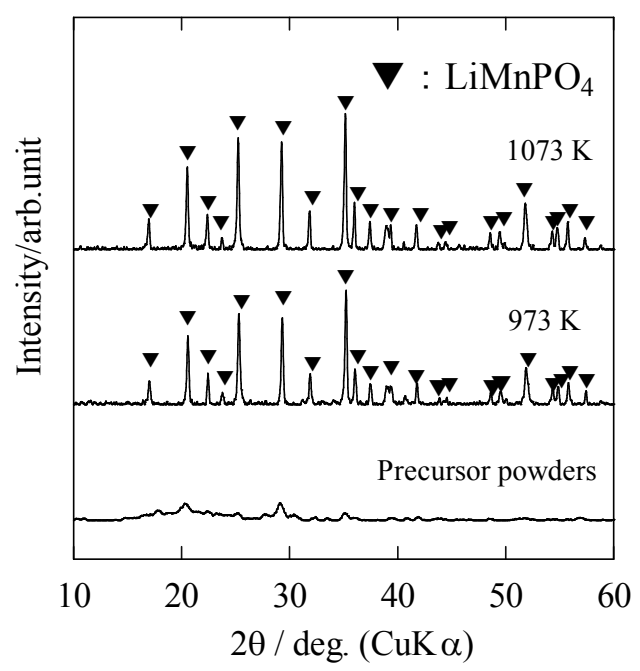

Fig.1 XRD patterns of precursor powders and $\mathrm{C} / \mathrm{LiMnPO}_{4}$ powders
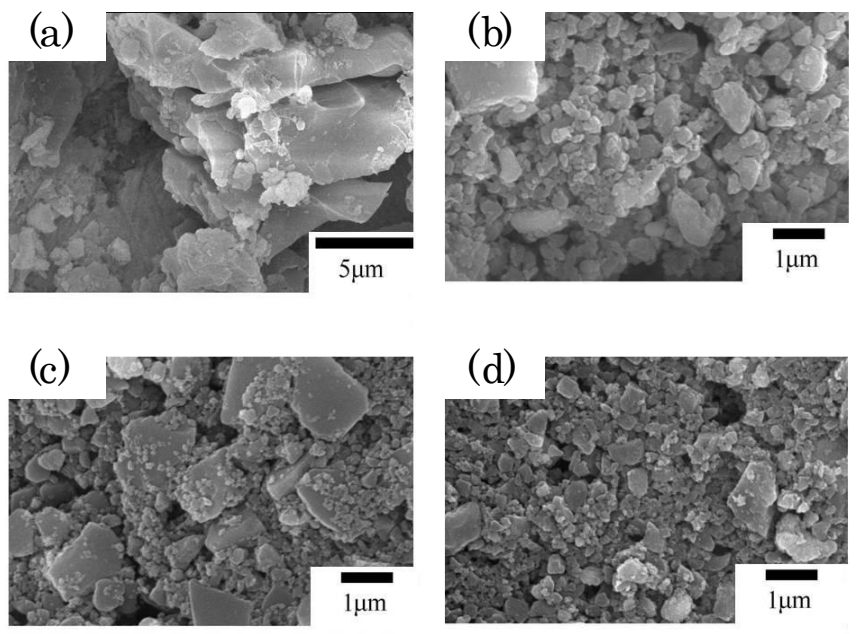

Fig.2 SEM photographs of $\mathrm{LiMnPO}_{4}$ powders, (a) precursor powders, (b) precursor powders after ball milling, (c) calcined at $973 \mathrm{~K}$, and (d) calcined at

$1073 \mathrm{~K}$ 

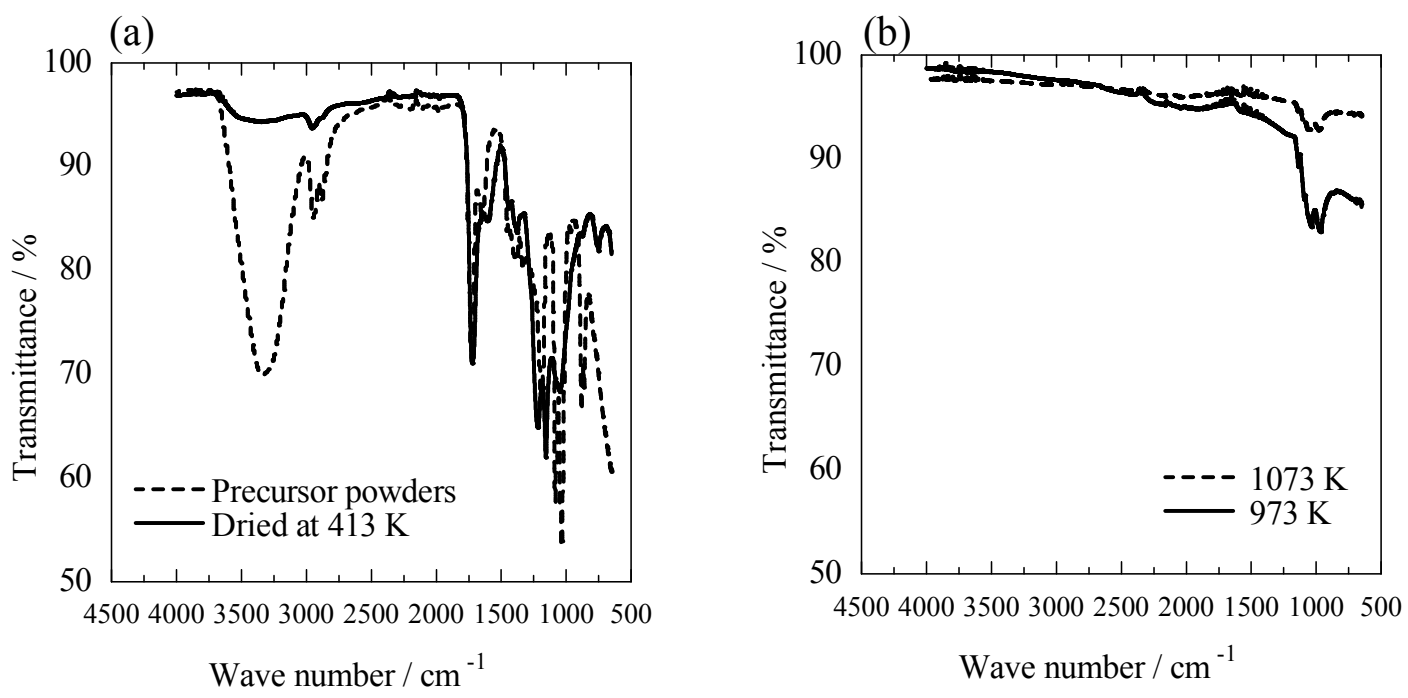

Fig.3 FT-IR spectra of $\mathrm{LiMnPO}_{4}$, (a) precursor powders and (b) calcined powders

Li:Mn:P = 1:1.02:0.98 and 1:0.99:0.98, respectively.These results were good agreement with the molar ratio of the starting solution $(1: 1: 1)$. It was found that homogeneous $\mathrm{LiMnPO}_{4}$ could be obtained by the complex polymerized method. The influence of particle morphology during calcination was examined by SEM observation. Figure 2 shows SEM photographs of the precursor powders and $\mathrm{C} / \mathrm{LiMnPO}_{4}$ powders calcined at $973 \mathrm{~K}$ for $3 \mathrm{~h}$ under an argon/hydrogen $(5 \%)$ atmosphere. The precursor powders had large particles about $5 \mu \mathrm{m}$ in size and bulk-type morphology. After the ball milling, their morphology changed to flake particles approximately $1 \mu \mathrm{m}$ in size. After calcination at $973 \mathrm{~K}$, the precursor powders were sintered to form both a plate-like morphology of more than $1 \mu \mathrm{m}$ in size and an irregular morphology of less than $1 \mu \mathrm{m}$ in size. Fine particles with irregular morphology were observed after calcination at $1073 \mathrm{~K}$. The SSA of the precursor powders determined by the BET method was $20.1 \mathrm{~m}^{2} / \mathrm{g}$. After ball milling, the SSA of the precursor powders increased to $301 \mathrm{~m}^{2} / \mathrm{g}$. This suggested that the precursor powders were milled by ball mill. On the other hand, the SSA of C/LiMnPO 4 powders calcined at $973 \mathrm{~K}$ and $1073 \mathrm{~K}$ decreased to $195 \mathrm{~m}^{2} / \mathrm{g}$ and $212 \mathrm{~m}^{2} / \mathrm{g}$, respectively, due to sintering. Figure 3 shows the IR spectra of both the precursor and $\mathrm{C} / \mathrm{LiMnPO}_{4}$ powders. The absorption peak of the ester bond was observed at $1750 \mathrm{~cm}^{-1}$ in the precursor powders. This result suggested that esterification occurred during the formation of the precursor powders. The absorption peak attributed to the $\mathrm{N}-\mathrm{O}$ bond in nitrates was also observed at $1400 \mathrm{~cm}^{-1}$. The absorption spectra of precursor powders dried at $413 \mathrm{~K}$ became shaper than those of the non-dried precursor powders, and the hydrogen bond peak was observed at $3250 \mathrm{~cm}^{-1}$. On the other hand, the peaks disappeared upon calcination. The absorption peak of the $\mathrm{P}-\mathrm{O}$ bands $\left(\mathrm{PO}_{4}{ }^{3-}\right)$

(a)

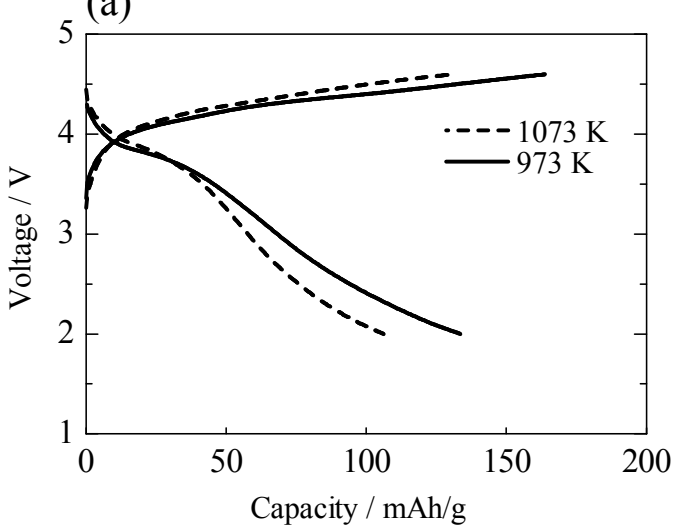

(b)

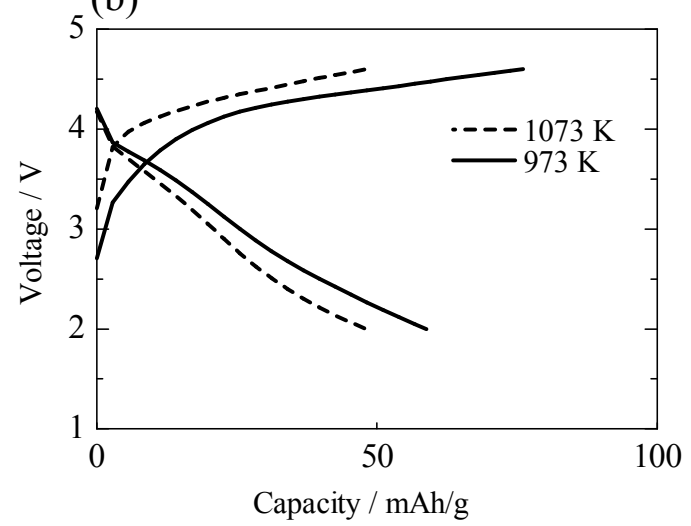

Fig.4 First charge and discharge capacities of $\mathrm{C} / \mathrm{LiMnPO}_{4}$ cathode, (a) at $0.1 \mathrm{C}$ and (b) at $1 \mathrm{C}$ 

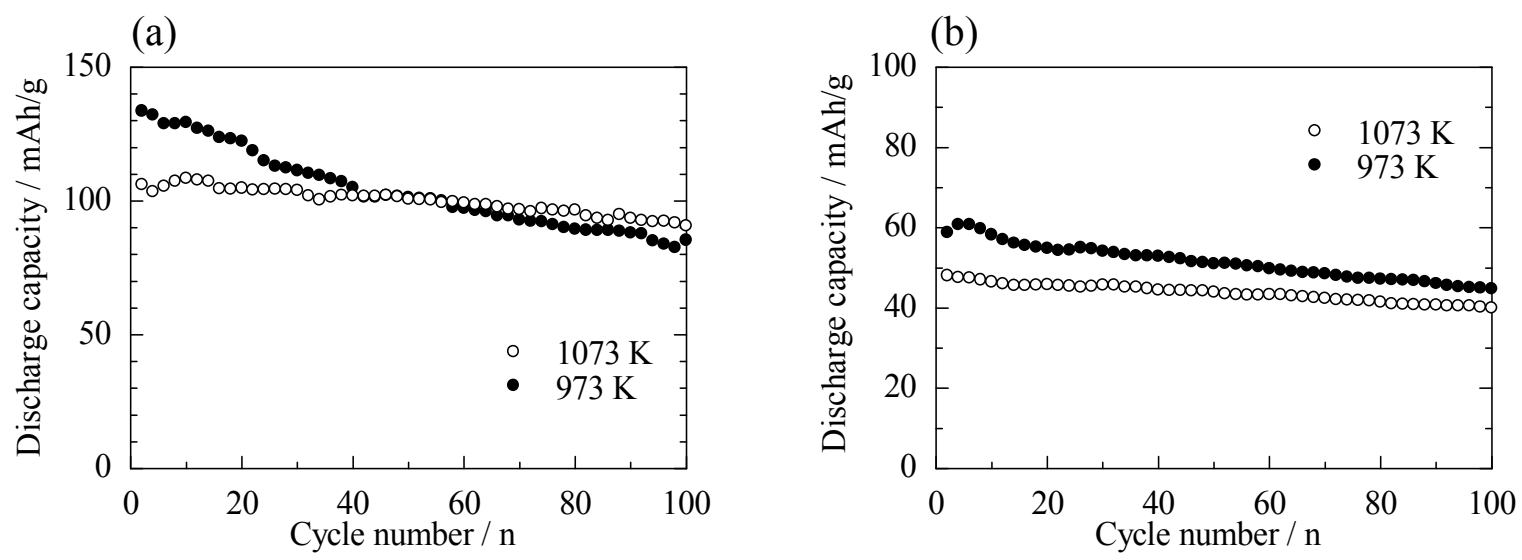

Fig.5 Cycle performance of $\mathrm{C} / \mathrm{LiMnPO}_{4}$ cathode, (a) at $0.1 \mathrm{C}$ and (b) at $1 \mathrm{C}$

were observed in all $\mathrm{C} / \mathrm{LiMnPO}_{4}$ powders at $1100 \mathrm{~cm}^{-1}$. Figure 4 shows the first charge and discharge curves of $\mathrm{C} / \mathrm{LiMnPO}_{4}$ cathodes at $0.1 \mathrm{C}$ and $1 \mathrm{C}$. The typical long plateaus of the olivine structure were not observed in these curves. At $0.1 \mathrm{C}$, the first discharge capacity of $\mathrm{C} / \mathrm{LiMnPO}_{4}$ cathodes calcined $973 \mathrm{~K}$ and $1073 \mathrm{~K}$ was $135 \mathrm{mAh} / \mathrm{g}$ and $105 \mathrm{mAh} / \mathrm{g}$, respectively. At $1 \mathrm{C}$, the first discharge of $\mathrm{C} / \mathrm{LiMnPO}_{4}$ cathodes calcined $973 \mathrm{~K}$ and $1073 \mathrm{~K}$ were $60 \mathrm{mAh} / \mathrm{g}$ and $50 \mathrm{mAh} / \mathrm{g}$, respectively. It was not observed the redox peak in cyclic voltammogram of $\mathrm{C} / \mathrm{LiMnPO}_{4}$ cathodes. These results suggested that the $\mathrm{Li}^{+}$ion was difficult to intercalate/deintercalate in the $\mathrm{LiMnPO}_{4}$ structure. Figures $5 \mathrm{a}$ and $5 \mathrm{~b}$ show the cycle performance of $\mathrm{C} / \mathrm{LiMnPO}_{4}$ cathodes at $0.1 \mathrm{C}$ and $1 \mathrm{C}$, respectively. After 100 cycles at $0.1 \mathrm{C}$, the discharge capacities of $\mathrm{C} / \mathrm{LiMnPO}_{4}$ cathodes calcined $973 \mathrm{~K}$ and $1073 \mathrm{~K}$ were $85.6 \mathrm{mAh} / \mathrm{g}$ and $90.4 \mathrm{mAh} / \mathrm{g}$, respectively; thus, the discharge capacities reduced to $64.0 \%$ and $85.1 \%$, respectively, of the first discharge capacities at $0.1 \mathrm{C}$. After 100 cycles at $1 \mathrm{C}$, the discharge capacities of $\mathrm{C} / \mathrm{LiMnPO}_{4}$ cathodes calcined at $973 \mathrm{~K}$ and $1073 \mathrm{~K}$ was $44.8 \mathrm{mAh} / \mathrm{g}$ and $40 \mathrm{mAh} / \mathrm{g}$, respectively; thus, the discharge capacities reduced to $74.7 \%$ and $80 \%$, respectively, of the first discharge capacities at $1 \mathrm{C}$.

\section{Conclusion}

$\mathrm{C} / \mathrm{LiMnPO}_{4}$ precursors were prepared by the complex polymerized method using a solution of citric acid and ethylene glycol. XRD measurements revealed that the crystal phase of calcined $\mathrm{C} / \mathrm{LiMnPO}_{4}$ powders was in agreement with an orthorhombic olivine structure. The first discharge capacities of $\mathrm{C} / \mathrm{LiMnPO}_{4}$ cathodes calcined at $973 \mathrm{~K}$ were $135 \mathrm{mAh} / \mathrm{g}$ and $60.0 \mathrm{mAh} / \mathrm{g}$ at $0.1 \mathrm{C}$ and 1 $\mathrm{C}$, respectively. After 100 cycles at $0.1 \mathrm{C}$ and $1 \mathrm{C}$, the discharge capacities reduced to $85.1 \%$ and $80.0 \%$, respectively, of the first discharge capacities.

\section{References}

[1] A. K. Padhi, K. S. Nanjundaswamy and J. B. Goodenough: J. Electrochem. Soc. 144 (1997), p. 1188

[2] J. D. Wilcox, M. M. Doeff, M. Marcinek and R. Kostecki: J. Electrochem. Soc. 154 (2007), p. A389

[3] S. L. Bewlay, K. Konstantinov, G. X. Wang, S. X. Dou and H. K. Liu: Mater. Lett. 58 (2004), p. 1788

[4] T. Drezen, N. H. Kwon, P. Bowen, I. Teerlinck, M. Isono and I. Exnar: J. Power Sources 174 (2007), p. 949

[5] T. Shiratsuchi, S. Okada, T. Doi and J. Yamaki: Electrochimi. Acta 54 (2009), p. 3154

[6] M. R. Yang, T. H. Teng and S. H. Wu: J. Power Sources 159 (2006), p. 307

[7] J. Szanics, T. Okubo and M. Kakihana: J. Alloy Compd. 281 (1998), p. 206

[8] C. R. Mariappan, C. Galven, M. P. Crosnier, F. Lopez, L. Berre and O. Bohnke: Solid State Chem. 179 (2006), p. 450 
Electroceramics in Japan XIV

doi:10.4028/www.scientific.net/KEM.485

Synthesis and Electrochemical Properties of C/LiMnPO<sub $>4</ s u b>$ Cathode Materials by Complex Polymerized Method

doi:10.4028/www.scientific.net/KEM.485.115 